\title{
PENGARUH KECEMASAN DAN KEMANDIRIAN BELAJAR TERHADAP KEMAMPUAN KOMUNIKASI MATEMATIKA SISWA SMA NEGERI DI KECAMATAN PASAR REBO
}

\author{
Somawati \\ Program Studi Pendidikan Matematika, Universitas Indraprasta PGRI \\ somadasay@gmail.com
}

\begin{abstract}
Abstrak
Tujuan dari penelitian ini adalah untuk menganalisis pengaruh kecemasan belajar dan kemandirian belajar siswa terhadap kemampuan komunikasi matematika siswa. Metode penelitian yang digunakan adalah metode penelitian survei korelasional dan analisis. Pengujian hipotesis menyimpulkan bahwa tidak terdapat pengaruh tidak langsung kecemasan belajar terhadap kemampuan komunikasi matematika siswa melalui kemandirian belajar siswa pada matematika siswa yang ditunjukkan oleh besarnya $t_{\text {hitung }}<t_{\text {tabel }}$ yaitu 0,131 $<1,665$ pada taraf signifikan 0,05.
\end{abstract}

Kata kunci : Kecemasan belajar, Kemandirian belajar, Kemampuan Komunikasi Matematika

\section{PENDAHULUAN}

Dunia pendidikan dan masyarakat ibarat dua sisi mata uang yang saling terkait satu sama lain. Dalam menjalankan fungsinya, pendidikan memerlukan masyarakat sebagai sumber daya manusia yang dapat menggerakkan roda pendidikan, sedangkan masyarakat dalam meningkatkan harkat dan martabatnya dimata masyarakat yang lain membutuhkan peran pendidikan sebagai pencapaian tujuan hidupnya. Begitu pentingnya sebuah pendidikan sehingga masyarakat dituntut untuk lebih selektif dalam memilih tempat untuk mengenyam pendidikan putra-putrinya, mengingat maraknya tempat-tempat pendidikan dengan tingkat pelayanan dan fasilitas yang berbeda-beda.

Salah satu hal yang sangat diperhatikan masyarakat dalam bidang pendidikan adalah mutu pendidikan. Pemerintah dalam hal ini Departemen Pendidikan Nasional memiliki kewenangan untuk mengatur ruang gerak dan pengaturan jalannya sistem kendali mutu pendidikan bangsa ini. Namun demikian, pendidikan di Indonesia saat ini masih belum mencapai target "mencerdaskan kehidupan bangsa", sesuai cita-cita dalam Pembukaan UUD 1945. Hal senadapun tersirat jelas mengenai keberhasilan tujuan pendidikan nasional dalam Bab II pasal 3 UU No. 20 Tahun 2003 tentang Sistem pendidikan Nasional yang menegaskan bahwa "pendidikan nasional bertujuan untuk mengembangkan potensi peserta didik agar menjadi manusia yang beriman dan bertakwa kepada Tuhan Yang Maha Esa, berakhlak mulia, sehat, berilmu, cakap, kreatif, mandiri, dan menjadi warga Negara yang demokratis serta bertanggung jawab”. Dengan kata lain, 
melalui pendidikan akan dicetak manusia-manusia berkualitas yang memiliki daya saing lokal maupun internasional. Namun realita yang ada sangat berkebalikan dengan yang dicita-citakan di atas. Menurut Suhartono (2008) jika realita kehidupan ini dipotret, gambar yang terlihat jelas adalah bahwa pada umumnya pendidikan sedang mengalami krisis. Ketika dunia pendidikan mengalami kemajuan luar biasa dengan kemampuan teknologi dan perindustriannya, moralitas kehidupan manusia justru mengalami kebangkrutan yang juga luar biasa. Itu berarti pendidikan mengemban tugas untuk mempersiapkan remaja bagi peranannya di masa depan agar kelak menjadi manusia berkualitas sebagaimana sesuai dengan sosok manusia ideal yang diamanahkan melalui Undang-undang Sistem Pendidikan Nasional (UUSPN).

Proses pendidikan khususnya di Indonesia selalu mengalami penyempurnaan yang nantinya akan menghasilkan suatu hasil pendidikan yang berkualitas. Para pengelola pendidikan telah melakukan hal-hal yang baik dalam rangka meningkatkan prestasi belajar peserta didik. Hal ini merupakan langkah awal untuk memperoleh kualitas sumber daya manusia. Sehubungan dengan hal tersebut, matematika menjadi salah satu jawaban atau solusi dari tantangan terhadap bangsa ini. Matematika sebagai dasar dan sekaligus penunjang segala ilmu telah terbukti melahirkan manusia-manusia yang berfikir logis, efektif dan selektif. Kecerdasan matematika sangatlah dibutuhkan oleh bangsa Indonesia dalam menyelesaikan permasalahan yang dimulai dengan proses menganalisis sampai pada tahapan penentuan solusi terbaiknya.

Selain itu keberadaan komunikasi juga sangat penting terutama dalam mengkomunikasikan matematika dalam memahami konsep ketika siswa memerankan situasi, menggambar, menggunakan objek, memberikan laporan dan penjelasan verbal. Keuntungan komunikasi matematika lainnya adalah siswa berbagi tanggung jawab dengan guru atas pembelajaran yang munculdalam pembelajaran tertentu. Hal ini sesuai dengan yang dikemukakan oleh Turmudi (2008) bahwa aspek komunikasi dan penalaran hendaknya menjadi aspek penting dalam pembelajaran matematika. Aspek komunikasi melatih siswa untuk mengkomunikasikan gagasannya, baik komunikasi lisan maupun komunikasi tulis.

Salah satu upaya untuk meningkatkan keberhasilan pendidikan pada bidang matematika yaitu dengan pembelajaran mandiri, dimana siswa melakukan sebagian besar pelajaran yang harus dilakukan. Kemandirian belajar merupakan salah satu unsur yang 
penting. Kemandirian menekankan pada aktivitas peserta didik dalam belajar yang penuh tanggung jawab atas keberhasilan dalam belajar. Kemandirian tercermin dalam kemantapan diri dan jenis pencapaian yang direalisasikan.

Kemandirian juga dapat diartikan sebagai kebebasan seseorang untuk menentukan masa depannya, hal ini menunjukkan bahwa orang tersebut dalam merencanakan hidupnya ditentukan oleh dirinya sendiri. Orang yang mandiri akan selalu berusaha untuk mengejar prestasi, penuh ketekunan, merencanakan serta mewujudkan harapannya sebagaimana sikapnya yang progresif dan ulet.

Kemandirian dalam belajar dapat dilihat dari tingkah laku yang ditujukan siswa pada saat proses belajar dan itu dapat dibedakan mana siswa yang memiliki kemandirian dalam belajar dengan siswa yang kurang memiliki kemandirian dalam belajar, seperti kesiapan siswa dalam menerima materi pelajaran biasanya siswa yang memiliki kemandirian dalam belajar sebelum guru memberikan materi, siswa tersebut sudah terlebih dahulu mempelajari materi sehingga pada saat guru menjelaskan siswa sudah siap untuk menerima materi, sedangkan siswa yang kurang memiliki kemandirian dalam belajar biasanya kurang peduli dengan persiapan sebelum menerima materi dari guru.

Untuk meningkatkan kemandirian siswa dapat dipupuk dengan memberikan tugastugas secara berkala yang sedapat mungkin dikerjakan secara mandiri. Sikap mandiri menunjukkan inisiatif, berusaha untuk mengejar prestasi, mempunyai rasa percaya diri dan mempunyai rasa ingin tahu yang besar. Dalam pengamatan peneliti didapat kenyataan bahwa dalam mengerjakan tugas-tugas yang diberikan guru, banyak terjadi penyalahgunaan yang dilakukan oleh siswa, misalnya mengambil jalan pintas dengan menyalin jawaban dari teman yang lain tanpa memahami jawaban tersebut. Bagi mereka adalah yang penting mengerjakan dan dapat menunjukkan pekerjaannya di depan guru.

Kemandirian belajar siswa mempunyai peranan penting dalam mencapai prestasi belajar siswa. Berbicara mengenai kemandirian belajar, hal ini sangat diperlukan terutama pada usia sekolah guna mempersiapkan individu-individu yang mampu mengarungi kehidupan masa mendatang yang semakin kompleks dan penuh tantangan. Oleh sebab itu, perkembangan kemandirian belajar siswa menuju ke arah kesempurnaan menjadi sangat penting untuk diikhtiarkan secara serius, sistemis, dan terprogram.

Selain itu, diharapkan dengan siswa yang memiliki kemandirian dalam belajarnya dapat mengatasi kecemasan-kecemasan yang bisa muncul dalam proses pembelajaran di 
kelas. Kita ketahui bersama bahwa pendidikan bukan hanya menekankan pada aspek jasmaniah saja, melainkan aspek psikologinya pun perlu mendapat perhatian, terutama dalam pemahaman siswa mengkomunikasikan mata pelajaran matematika.

Untuk mengkaji permasalahan di atas secara lebih mendalam maka penelitian ini memfokuskan pada pengaruh faktor kecemasan belajar siswa, kemandirian belajar siswa terhadap kemampuan komunikasi matematika siswa dalam judul "Pengaruh Kecemasan Belajar dan Kemandirian Belajar Siswa Terhadap Kemampuan Komunikasi Matematika Siswa SMA Negeri Di Kecamatan Pasar Rebo"

\section{TINJAUAN PUSTAKA}

\section{Kemampuan Komunikasi Matematika}

Tujuan belajar pada hakikatnya adalah perubahan tingkah laku yang meliputi pengetahuan, sikap, dan keterampilan. Kemampuan merupakan hal yang penting dalam proses pembelajaran karena sebagai pendukung terbentuknya prestasi baik akademik maupun non akademik seorang siswa. Menurut Milman Yusdi (2010) mengartikan bahwa kemampuan adalah kesanggupan, kecakapan, kekuatan kita berusaha dengan diri sendiri. Menurut Stephen P. Robbin \& Timonthy A. Judge (2009) kemampuan berarti kapasitas seseorang individu untuk melakukan beragam tugas dalam suatu pekerjaan. Lebih lanjut, Stephen P. Robbins \& Timonthy A. Judge menyatakan bahwa kemampuan keseluruhan seorang individu pada dasarnya terdiri atas dua kelompok faktor, yaitu:

a. Kemampuan intelektual yang merupakan kemampuan yang dibutuhkan untuk melakukan berbagai aktifitas mental seperti berfikir, menalar dan memecahkan masalah.

b. Kemampuan fisik merupakan kemampuan melakukan tugas-tugas yang menuntut stamina, keterampilan, kekuatan, dan karakteristik serupa lainnya.

Berdasarkan beberapa teori diatas dapat disimpulkan bahwa kemampuan adalah kesanggupan, kecakapan, kekuatan dan kemampuan yang dimiliki seseorang untuk dapat menyelesaikan sesuatu pekerjaan yang didapat dari bawaan sejak lahir maupun dengan cara dipelajari.

Komunikasi merupakan suatu topik yang sering diperbincangkan, bukan hanya dikalangan ilmuwan komunikasi, melainkan juga dikalangan awam, sehingga kata komunikasi itu sendiri memiliki terlalu banyak arti yang berlainan. Menurut Effendy 
(2007) kata komunikasi atau communication dalam bahasa inggris berasal dari kata latin communis yang berarti sama, sama disini maksudnya adalah sama makna, jadi jika dua orang telibat dalam komunikasi maka komunikasi akan terjadi atau berlangsung selama ada kesamaan makna mengenai apa yang dikomunikasikan, yakni baik si penerima maupun si pengirim sepaham dari suatu pesan tertentu.

Menurut Professor Wilbur Schramm dalam Cangara (2006) mengatakan tanpa komunikasi, tidak mungkin terbentuk suatu masyarakat. Sebaliknya tanpa masyarakat, manusia tidak dapat mengembangkan komunikasi. Berkomunikasi dengan baik akan memberi pengaruh langsung terhadap struktur keseimbangan seseorang dalam masyarakat, apakah ia seorang dokter, dosen, manager dan sebagainya.

Menurut Onong Cahyana dalam Effendy (2007), komunikasi adalah proses penyampaian pesan oleh sesorang kepada orang lain untuk memberitahu, mengubah sikap, pendapat, atau perilaku, baik secara lisan (langsung) ataupun tidak langsung (melalui media). Kridalaksana (2008) berpendapat bahwa kemampuan komunikasi adalah kemampuan komunikator (orang yang menyampaikan informasi) untuk mempergunakan bahasa yang dapat diterima dan memadai secara umum.

Menurut Berelson\&Steiner dalam Mulyana (2008), mengartikan kemampuan komunikasi sebagai kemampuan menstranmisi informasi, gagasan, emosi, keterampilan, dengan mnggunakan simbol-simbol seperti perkataan, gambar, figure, grafik dan sebagainya. Sedangkan menurut Book dalam Cangara (2006), kemampuan komunikasi adalah proses simbolik yang menghendaki individu agar dapat mengatur lingkungan dalam hubungan sosialnya melalui pertukaran informasi untuk mengubah sikap dan tingkah laku orang lain.

Berdasarkan beberapa teori diatas dapat disimpulkan bahwa kemampuan komunikasi adalah kemampuan seseorang dalam mentransmisi informasi, gagasan, emosi, keterampilan atau sesuatu yang diketahuinya kepada orang lain baik secara langsung melalui lisan maupun tidak langsung melalui simbol-simbol seperti perkataan, gambar, figure, grafik dan sebagainya.

Matematika menjadi salah satu jawaban atau solusi dari tantangan terhadap bangsa ini. Matematika sebagai dasar dan sekaligus penunjang segala ilmu telah terbukti melahirkan manusia-manusia yang berfikir logis, efektif dan selektif. Suriasumantri dalam Sappaile (2007) menyatakan bahwa matematika merupakan salah satu puncak 
gemilang intelektual. Ciri utama matematika ialah metode dalam penalaran (reasoning). Sedangkan menurut Sudiarta (2007) matematika mempunyai karakteristik yang khas, yaitu memiliki content yang memuat bangunan konsep-konsep abstrak, sistem-sistem aksioma, prosedur algoritma yang pada umumnya bersifat dedukatif. Lain halnya dengan Maesarah (2010) yang beranggapan bahwa banyak siswa yang menganggap matematika adalah mata pelajaran yang sangat sulit, menjemukan hanya berkaitan dengan bilangan, hanya berkaitan dengan kegiatan menghafal dan lain sebagainya.

Dari pemaparan teori para ahli di atas, maka dapat disimpulkan bahwa matematika adalah suatu disiplin ilmu tentang konsep-konsep berfikir tentang aljabar, analisis, dan geometri yang dapat diakselerasikan dalam berbagai disiplin ilmu lainnya seperti permasalahan sosial, ekonomi dan alam.

Komunikasi merupakan cara berbagai ide dan memperjelas pemahaman. Melalui komunikasi ide dapat dicerminkan, diperbaiki, didiskusikan, dan dikembangkan. Sedangkan Sudrajat (2008) mengatakan ketika seorang siswa memperoleh informasi berupa konsep matematika yang diberikan guru maupun yang diperoleh dari bacaan, maka saat itu terjadi transformasi informasi matematika dan sumber kepada siswa tersebut. Wahyudin (2008) berpendapat bahwa komunikasi adalah bagian esensial dari matematika dan pendidikan matematika.

Berdasarkan beberapa teori diatas dapat disimpulkan bahwa kemampuan komunikasi matematika siswa adalah kemampuan berinteraksi siswa dengan lingkungannya di kelas (dengan cara berbicara, mendengar, membaca dan menulis) dalam menyampaikan informasi, bertanya dan mengungkapkan pendapat atau gagasan dalam pembelajaran matematika baik secara lisan maupun tulisan.

\section{Kemandirian Belajar}

Salah satu upaya untuk meningkatkan keberhasilan pendidikan pada bidang matematika yaitu dengan pembelajaran mandiri, dimana siswa melakukan sebagian besar pelajaran yang harus dilakukan. Menurut Basri (2005) mengemukakan bahwa kemandirian secara psikologis dan mentalis yaitu keadaan seseorang yang dalam hidupnya mampu memutuskan dan mengerjakan sesuatu tanpa bantuan dari orang lain. Menurut Brawer dalam Chabib (2004) menyatakan bahwa kemandirian adalah suatu perasaan otonomi. Perasaan otonomi diartikan sebagai perilaku yang terdapat dalam diri 
seseorang yang timbul karena kekuatan dorongan dari dalam diri tidak karena terpengaruh oleh orang lain.

Menurut Parker (2006) mengemukakan bahwa kemandirian adalah suatu kondisi dimana seseorang tidak tergantung pada otoritas dan tidak membutuhkan arahan. Kemandirian juga mencakup diri sendiri dan menyelesaikan masalahnya sendiri. Sedangkan Lie dan Prasasti dalam Maulidiyah (2005) menyatakan pendapatnya tentang kemandirian, bahwa kemandirian adalah kemampuan untuk melakukan kegiatan atau tugas sehari-hari sendiri atau dengan sedikit bimbingan, sesuai dengan tahapan perkembangan dan kapasitasnya.

Dari pemaparan teori para ahli di atas, maka dapat disimpulkan bahwa kemandirian adalah dimensi kekuatan seseorang yang mampu memutuskan dan mengerjakan sesuatu atas dorongan sendiri, tanpa arahan orang lain yang sebelumnya didasari atas pertimbangan dan dapat mempertanggung jawabkan terhadap segala keputusan yang telah diambil.

Menurut Slameto (2010) belajar adalah proses usaha yang dilakukan seseorang untuk memperoleh suatu perubahan tingkah laku yang baru secara keseluruhan, sebagai hasil pengalamannya sendiri dalam interaksi dengan lingkungannya. Dalam Sugihartono (2007) Santrock dan Yussen mendefinisikan belajar sebagai perubahan yang relatif permanen karena adanya pengalaman. Reber, dalam sumber yang sama mendefinisikan belajar dalam dua pengertian. Pertama, belajar sebagai proses memperoleh pengetahuan dan kedua, belajar sebagai perubahan kemampuan bereaksi yang relatif langgeng sebagai hasil latihan yang diperkuat.

Menurut Iskandar (2009) belajar didefiniskan sebagai suatu proses perubahan yang terjadi perubahan perilaku yang dilakukan secara sadar dari reaksi dan situasi yang dihadapi.Sedangkan menurut Poerwadarminta (2007) mengemukakan bahwa belajar adalah berusaha memperbaiki kepandaian. Belajar adalah mandiri.Sardiman (2010) mendefinisikan belajar sebagai usaha penguasaan materi ilmu pengetahuan yang merupakan sebagian kegiatan menuju terbentuknya kepribadian seutuhnya. Lain halnya dengan Trianto (2010) mengemukakan bahwa proses belajar terjadi melalui banyak cara baik disengaja maupun tidak disengaja dan berlangsung sepanjang waktu dan menuju pada suatu perubahan pada diri pembelajar. Perubahan yang dimaksud Trianto disini 
adalah perubahan perilaku tetap berupa pengetahuan, pemahaman, keterampilan, dan kebiasaan yang baru diperoleh individu.

Dari pemaparan teori para ahli di atas, maka dapat disimpulkan bahwa belajar adalah proses usaha yang dilakukan seseorang secara sadar dari reaksi aktif dan situasi yang dihadapi yang relatif permanen/ langgeng guna menambah dan mengumpulkan sejumlah pengetahuan melalui pengalaman dalam interaksi dengan lingkungannya yang dimanifestasikan dalam perubahan pola-pola respon tingkah laku yang baru dan nyata.

Kemandirian belajar merupakan salah satu unsur yang penting. Kemandirian menekankan pada aktivitas peserta didik dalam belajar yang penuh tanggung jawab atas keberhasilan dalam belajar. Kemandirian tercermin dalam kemantapan diri dan jenis pencapaian yang direalisasikan. Menurut Sukmadinata (2011) kemandirian belajar bertujuan agar siswa mampu bertanggung jawab dalam mengatur dan mendisiplinkan dirinya dan mengembangkan kemampuan belajar atas kemampuan sendiri.Sedangkan Sumahamijaya (2001) mengemukakan bahwa kemandirian belajar adalah sikap mental dalam belajar yang tercermin dalam rasa tanggung jawab, percaya diri, inisiatif, dan tidak mengelak dari keharusan mengambil resiko yang sepantasnya.

Haris Mujiman (2007) memberikan pendapatnya tentang kemandirian belajar yaitu kegiatan belajar aktif yang didorong oleh niat dan motif untuk menguasai suatu kompetensi guna mengatasi suatu masalah dan dibangun dengan bekal pengetahuan atau kompetensi yang dimiliki.Menurut Samana dalam Syarifudin (2007) mengartikan kemandirian belajar sebagai cara bagaimana ia dapat mengatur serta mengendalikan kegiatan belajarnya atas dasar pertimbangan, keputusan dan tanggung jawab sendiri.

Dari pemaparan teori para ahli di atas, maka dapat disimpulkan bahwa kemandirian belajar adalah hasil kemampuan seseorang/siswa yang mendisiplinkan dirinya dengan mengatur sendiri kegiatan belajarnya, atas inisiatif sendiri dan dapat dipertanggung jawabkan tanpa ada rasa bergantung kepada orang lain.

\section{Kecemasan Belajar}

Selain itu, diharapkan dengan siswa yang memiliki kemandirian dalam belajarnya dapat mengatasi kecemasan-kecemasan yang bisa muncul dalam proses pembelajaran di kelas. Menurut Singgih D. Gunarsa (2008) kecemasan merupakan "suatu perubahan suasana hati, perubahan di dalam dirinya sendiri yang timbul dari dalam tanpa adanya perangsang dari luar. Menurut Spielbelger seperti dikutip Slameto (2010) membedakan 
atas dua bagian, yaitu pertama, kecemasan sebagai satu sifat yang kecenderungan pada diri seseorang untuk merasa terancam oleh sejumlah kondisi yang sebenaranya tidak bahaya, dan yang kedua, kecemasan sebagai suatu keadaan yaitu suatu keadaan atau kondisi emosional sementara pada diri seseorang yang ditandai dengan perasaan tegang dan kekhawatiran yang dihayati secara sadar serta bersifat subyektif dan meningginya aktifitas sistem saraf otonom. Sebagai suatu keadaan, kecemasan biasanya berhubungan dengan situasi-situasi lingkungan yang khusus, misalnya situasi tes.

Dari pemaparan para ahli di atas, maka dapat disimpulkan bahwa kecemasan adalah manifestasi dari berbagai proses emosi yang bercampur baur, yang terjadi ketika orang sedang mengalami tekanan perasaan dan pertentangan batin (Konflik) tanpa adanya perangsang dari luar.

Menurut Slameto (2010) bahwa dalam lingkungan belajar yang tidak terstruktur, siswa dengan tingkat kecemasan yang tinggi maka prestasinya akan buruk. Pengajar harus sadar bahwa alat-alat bantu ingatan, pengajaran yang sistematis, dan kesempatan praktek dapat menghilangkan tekanan yang dirasakan oleh siswa dengan tingkat kecemasan tinggi.

Dari pemaparan teori para ahli di atas, maka dapat disimpulkan bahwa kecemasan belajar adalah salah satu bentuk perasaan seorang siswa ketika belajar atau ujian terutama ujian matematika adalah terjadinya perasaan yang tidak mengenakkan atau merasa takut dan tegang. Beberapa siswa terkadang menyikapi ujian sebagai suatu permasalahan dalam hidupnya, baik karena nantinya ia akan malu karena tidak mendapat nilai yang bagus maupun karena merasa tidak percaya diri dengan persiapan yang dimilikinya.

\section{METODE}

Penelitian ini dilaksanakan di SMA Negeri di Kecamatan Pasar Rebo yang terdapat 5 SMA Negeri yaitu SMA Negeri 106, SMA Negeri 104, SMA Negeri 39, SMA Negeri 88 dan SMA Negeri 98. Dari kelima SMA Negeri tersebut, peneliti mengadakan penelitian di dua sekolah, yaitu di SMA Negeri 104 dan SMA Negeri 98. Koresponden berasal dari siswa/i kelas sebelas (XI). Penelitian ini dilaksanakan pada semester satu tahun ajaran 2015/2016 selama 3 bulan, yaitu selama bulan Agustus sampai dengan Desember 2015. Dalam pelaksanaannya, penelitian ini terbagi atas tiga tahapan yaitu tahap persiapan, tahap pengumpulan data dan tahap pengolahan data. 
Penelitian ini dilakukan dengan menggunakan metode survey korelasional dan analisis yang digunakan untuk menguji hipotesis dilakukan dengan analisis jalur. Sugiyono (2010) ada tiga variabel yang diteliti yaitu variabel bebas yang terdiri dari kecemasan belajar dan kemandirian belajar siswa dan variabel terikat adalah kemampuan komunikasi matematika siswa. Untuk mempermudah memahami konsep penelitian ini, maka diharapkan rancangan penelitian ini dapat memberikan gambaran yang jelas.

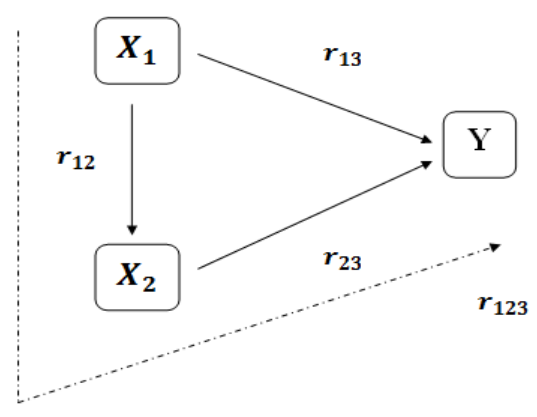

Gambar 1. Desain Penelitian

Keterangan :

$X_{1}=$ Kecemasan belajar siswa

$X_{1}=$ Kemandirian belajar siswa

$Y=$ Kemampuan komunikasi Matematika Siswa

Paradigma sederhana dengan dua variabel independen yaitu $X_{1}$ dan $X_{2}$ serta satu variabel dependen yaitu $\mathrm{Y}$.

Tteknik pengambilan sampel dalam penelitian ini adalah probability sampling yang dikhususkan pada simple random sampling karena pengambilan anggota dari populasi dilakukan secara acak tanpa memperhatikan strata yang ada dalam populasi itu yaitu pada siswa kelas XI SMA Negeri 104 dan SMA Negeri 98 Jakarta. Jumlah anggota sampel adalah 80 siswa. Teknik dalam proses pengumpulan data dilakukan beberapa teknik seperti tes soal dan angket.

\section{HASIL DAN PEMBAHASAN}

\section{Analisis deskripsi}

\section{Kemampuan komunikasi matematika}

Data kemampuan komunikasi matematika yang diperoleh dari koresponden yang terdiri dari 10 butir pertanyaan yang dijawab oleh 80 orang responden. Skor yang 
diperoleh adalah skor terendah 48, skor tertinggi 100, skor rata-rata sebesar 80,39, median sebesar 84,00, modus sebesar 93,00 dan simpangan baku sebesar 14,931. Angka simpangan baku sebesar 14,931 atau sama dengan 18,57\% dari rata-rata, menunjukkan perbedaan kemampuan komunikasi matematika antar responden termasuk rendah. hal ini menunjukkan bahwa kemampuan komunikasi matematika dari responden tidak banyak beragam.Dari deskripsi tersebut juga dapat dilihat bahwa nilai rata-rata dan median hampir sama, yaitu 80,39 dan 84,00. hal ini menunjukkan bahwa kemampuan komunikasi matematika pada penelitian ini cukup representatif. Sedangkan kemampuan komunikasi yang berada di atas rata-rata lebih banyak disbanding yang berada di bawah rata-rata menunjukkan bahwa siswa yang mempunyai kemampuan komunikasi matematika yang tinggi lebih banyak daripada yang rendah. Deskripsi data tersebut dapat dilihat pada lampiran.

\section{Kemandirian belajar}

Skor kemandirian belajar yang diperoleh dari responden mempunyai skor terendah 80 , skor tertinggi 142, skor rata-rata sebesar 109,70, median sebesar 108,00, modus sebesar 105 dan simpangan baku sebesar 12,689. Angka simpangan baku sebesar 12,689 atau sama dengan 11,57\% dari rata-rata, menunjukkan perbedaan kemandirian belajar antar responden termasuk rendah. Hal ini menunjukkan bahwa kemandirian belajar dari responden tidak banyak beragam. Dari deskripsi tersebut juga dapat dilihat bahwa nilai rata-rata dan median hampir sama, yaitu 109,70 dan 108,00. Hal ini menunjukkan bahwa kemandirian belajar siswa pada penelitian ini cukup representatif. Sedangkan kemandirian belajar siswa yang berada di atas rata-rata lebih banyak dibandingkan yang berada di bawah rata-rata. Hal ini menunjukkan bahwa siswa yang mempunyai kemandirian belajar yang tinggi lebih banyak daripada yang rendah.

\section{Kecemasan belajar}

Skor kecemasan belajar yang diperoleh dari responden mempunyai skor terendah 34 , skor tertinggi 125 , skor rata-rata sebesar 83,29 , median sebesar 77,50, modus sebesar 70,00 dan simpangan baku sebesar 23,149. Angka simpangan baku sebesar 23,149 atau sama dengan $27,79 \%$ dari rata-rata, menunjukkan perbedaan kecemasan belajar antar responden termasuk rendah. hal ini menunjukkan bahwa kecemasan belajar dari responden tidak banyak beragam.Dari deskripsi tersebut juga dapat dilihat bahwa nilai rata-rata dan median hampir sama yaitu 83,29 dan 77,50. Hal ini menunjukkan bahwa 
kecemasan beajar pada penelitian ini cukup representatif. Sedangkan kecemasan beajar yang berada dia atas rata-rata lebih sedikit dibanding dengan yang berada di bawah ratarata. Hal ini menunjukkan bahwa siswa yang mempunyai kecemasan belajar yang tinggi lebih sedikit daripada yang rendah.

\section{Pengujian Persyaratan Data}

Pengujian persyaratan analisis data yang dilakukan pada penelitian ini adalah pengujian normalitas dan linieritas garis regresi antara variabel bebas dan variabel terikat.

Tabel 1. Rekapitulasi Hasil Pengujian Normalitas

\begin{tabular}{|c|c|c|c|c|}
\hline & & $\begin{array}{c}\text { Kecemasan } \\
\text { Belajar }\end{array}$ & $\begin{array}{c}\text { Kemandirian } \\
\text { Belajar }\end{array}$ & $\begin{array}{l}\text { Kemampuan } \\
\text { Komunikasi } \\
\text { Matematika }\end{array}$ \\
\hline $\mathrm{N}$ & & 80 & 80 & 80 \\
\hline \multirow[t]{2}{*}{ Normal Parameters ${ }^{a . b}$} & Mean & 83.29 & 109.70 & 80.39 \\
\hline & Std. Deviation & 23.149 & 12.689 & 14.931 \\
\hline \multirow[t]{3}{*}{ Most Extreme Differences } & Absolute & .119 & .090 & .145 \\
\hline & Positive & .119 & .090 & .094 \\
\hline & Negative & -.103 & -.061 & -.145 \\
\hline Test Statistic & & .119 & .090 & .145 \\
\hline Asymp. Sig. (2-tailed) & & $.007^{\mathrm{c}}$ & $.172^{\circ}$ & $.000^{\circ}$ \\
\hline
\end{tabular}

Hasil pengujian normalitas menunjukkan bahwa seluruh variabel berdistribusi normal. Sedangkan pengujian kelinieritas garis regresi menggunakan ANAVA diperoleh hasil bahwa persamaan regresi yang dibentuk antara kedua variabel adalah linier, sehingga dapat dilanjutkan dengan analisis jalur.

\section{Pengujian Hipotesis Penelitian}

Tabel 2. Rekapitulasi Hasil Perhitungan Persamaan Regresi Pengaruh Variabel X1 terhadap X2

\begin{tabular}{|c|c|c|c|c|c|c|c|c|c|c|c|}
\hline \multicolumn{12}{|c|}{ Coefficients $^{a}$} \\
\hline \multirow[b]{2}{*}{ Model } & & \multicolumn{2}{|c|}{$\begin{array}{c}\text { Unstandardized } \\
\text { Coefficients }\end{array}$} & \multirow{2}{*}{\begin{tabular}{|c|}
$\begin{array}{c}\text { Standardiz } \\
\text { ed } \\
\text { Coefficient } \\
\text { s }\end{array}$ \\
Beta \\
\end{tabular}} & \multirow[b]{2}{*}{$t$} & \multirow[b]{2}{*}{ Sig. } & \multicolumn{3}{|c|}{ Correlations } & \multicolumn{2}{|c|}{ Collinearity Statistics } \\
\hline & & $\mathrm{B}$ & Std. Error & & & & Zero-order & Partial & Part & Tolerance & VIF \\
\hline 1 & (Constant) & 83.685 & 22.809 & & 3.669 & .000 & & & & & \\
\hline & $\begin{array}{l}\text { Kemandirian } \\
\text { Belajar }\end{array}$ & .004 & .207 & .066 & 3.828 & .986 & .002 & .002 & .002 & 1.000 & 1.000 \\
\hline
\end{tabular}

Dari Tabel 2 terlihat bahwa nilai Sig 0.000 dan $t_{\text {hitung }}=3,828$, sedangkan $t_{\text {tabel }}=$ 1,665. Karena nilai Sig. $<0,05$ dan nilai $t_{\text {hitung }}>\mathrm{t}_{\text {tabel }}$ maka $\mathrm{H}_{0}$ ditolak yang berarti terdapat pengaruh langsung antara variabel kemandirian belajar siswa $\left(\mathrm{X}_{1}\right)$ dengan variabel kecemasan belajar siswa $\left(\mathrm{X}_{2}\right)$. 
Tabel 3. Koefisien Jalur $\mathrm{P}_{31}$ dan $\mathrm{P}_{32}$

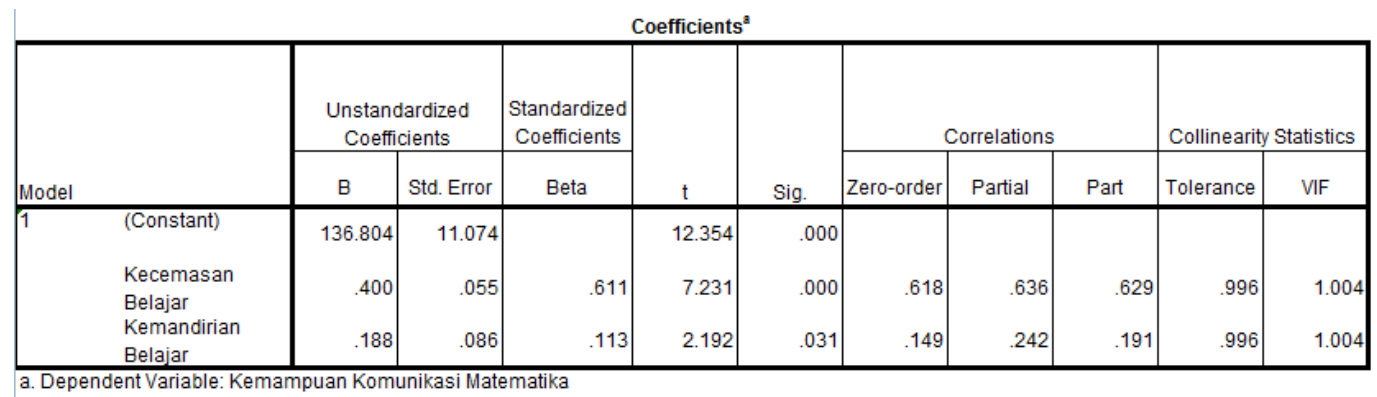

Dari tabel 3 terlihat bahwa nilai Sig 0.000 dan $t_{\text {hitung }}=7,231$, sedangkan $t_{\text {tabel }}=$ 1,665. Karena nilai Sig. $<0,05$ dan nilai $t_{\text {hitung }}>t_{\text {tabel }}$ maka $\mathrm{H}_{0}$ ditolak yang berarti terdapat pengaruh langsung antara variabel kecemasan belajar siswa $\left(\mathrm{X}_{1}\right)$ dengan variabel kemampuan komuniaksi matematika siswa (Y).

Dari tabel yang sama terlihat bahwa nilai Sig 0,000 dan thitung $=2,192$, sedangkan $\mathrm{t}_{\text {tabel }}=1,665$. Karena nilai Sig $<0,05$ dan nilai $\mathrm{t}_{\text {hitung }}>\mathrm{t}_{\text {tabel }}$ maka $\mathrm{H}_{0}$ ditolak yang berarti terdapat pengaruh langsung antara variabel kemandirian belajar $\left(\mathrm{X}_{2}\right)$ dengan kemampuan komunikasi matematika siswa (Y).

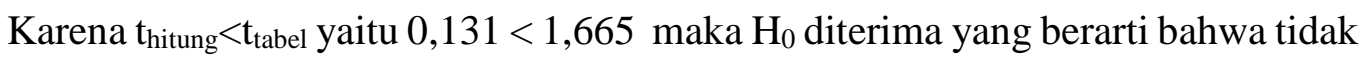
terdapat pengaruh tidak langsung antara kecemasan $\left(\mathrm{X}_{1}\right)$ terhadap kemampuan komunikasi matematika siswa $(\mathrm{Y})$ melalui kemandirian belajar siswa $\left(\mathrm{X}_{2}\right)$.

\section{HASIL DAN PEMBAHASAN}

Berdasarkan hasil analisis data SPSS versi 22.0 dapat diketahui Persamaan regresi $\bar{Y}=0,066 X_{1}$. Yang berarti bahwa koefisien regresi kecemasan belajar sebesar 0,066 memberikan pemahaman bahwa setiap penambahan satu satuan atau satu tingkatan kemandirian belajar siswa akan berdampak pada menurunnya kecemasan belajar siswa sebesar 0,066 satuan. Berdasarkan hasil penelitian, maka hasil penelitian ini yaitu bahwa terdapat pengaruh langsung kecemasan belajar siswa terhadap kemandirian belajar siswa.

Berdasarkan hasil analisis data SPSS versi 22.0 dapat diketahui Persamaan regresi $\bar{Y} .=0,611 X_{1}+0,113 X_{2}$. Yang berarti bahwa koefisien regresi kecemasan belajar sebesar 0,611 memberikan pemahaman bahwa setiap penambahan satu satuan atau satu tingkatan kecemasan belajar siswa akan berdampak pada menurunnya kemampuan komunikasi matematika siswa sebesar 0,611 satuan. Berdasarkan hasil perhitungan, maka hasil 
penelitian ini yaitu bahwa terdapat pengaruh langsung kecemasan belajar terhadap kemampuan komunikasi matematika siswa.

Berdasarkan hasil analisis data SPSS versi 22.0 dapat diketahui Persamaan regresi $\overline{\mathrm{Y}}=0,611 \mathrm{X}_{1}+0,113 \mathrm{X}_{2}$. Yang berarti bahwa koefisien regresi kemandirian belajar sebesar 0,113 memberikan pemahaman bahwa setiap penambahan satu satuan atau satu tingkatan kemandirian belajar akan berdampak pada meningkatnya kemampuan komunikasi matematika siswa sebesar 0,113 satuan. Berdasarkan hasil perhitungan, maka hasil ini yaitu bahwa terdapat pengaruh langsung kemandirian belajar siswa terhadap kemampuan komunikasi matematika siswa.

Berdasarkan hasil analisis data SPSS versi 22.0 dapat diketahui Persamaan regresi $t_{\text {hitung }}=0,021$, maka hasil penelitian ini yaitu bahwa tidak terdapat pengaruh tidak langsung kecemasan belajar terhadap kemampuan komunikasi matematika siswa melalui kemandirian belajar siswa pada matematika siswa.

\section{SIMPULAN}

Setelah diadakan penelitian dan analisis data tentang Kecemasan belajar dan Kemandirian Belajar Siswa terhadap Kemampuan Komunikasi Matematika Siswa SMA Negeri se Kecamatan Pasar Rebo dapat ditarik kesimpulan sebagai berikut :

1) Terdapat pengaruh langsung antara variabel kecemasan belajar siswa $\left(X_{1}\right)$ dengan variabel kemandirian belajar siswa $\left(\mathrm{X}_{2}\right)$ dengan berdasarkan nilai Sig 0.000 dan $\mathrm{t}_{\text {hitung }}$ $=3,828$, sedangkan $t_{\text {tabel }}=1,665$. Karena nilai Sig. $<0,05$ dan nilai $t_{\text {hitung }}>t_{\text {tabel }}$ maka $\mathrm{H}_{0}$ ditolak yang berarti terdapat pengaruh langsung antara variabel kemandirian belajar siswa $\left(\mathrm{X}_{1}\right)$ dengan variabel kecemasan belajar siswa $\left(\mathrm{X}_{2}\right)$.

2) Terdapat pengaruh langsung antara variabel kecemasan belajar siswa $\left(X_{1}\right)$ dengan variabel kemampuan komuniaksi matematika siswa (Y) dengan berdasarkan nilai Sig 0.000 dan $t_{\text {hitung }}=7,231$, sedangkan $t_{\text {tabel }}=1,665$. Karena nilai Sig. $<0,05$ dan nilai $t_{\text {hitung }}>\mathrm{t}_{\text {tabel }}$ maka $\mathrm{H}_{0}$ ditolak yang berarti terdapat pengaruh langsung antara variabel kecemasan belajar siswa $\left(\mathrm{X}_{1}\right)$ dengan variabel kemampuan komuniaksi matematika siswa $(Y)$.

3) Terdapat pengaruh langsung antara variabel kemandirian belajar $\left(X_{2}\right)$ dengan kemampuan komunikasi matematika siswa (Y) dengan berdasarkan nilai Sig 0,000 dan $t_{\text {hitung }}=2,192$, sedangkan $t_{\text {tabel }}=1,665$. Karena nilai $\operatorname{Sig}<0,05$ dan nilai $t_{\text {hitung }}>$ 
$\mathrm{t}_{\text {tabel }}$ maka $\mathrm{H}_{0}$ ditolak yang berarti terdapat pengaruh langsung antara variabel kemandirian belajar $\left(\mathrm{X}_{2}\right)$ dengan kemampuan komunikasi matematika siswa (Y).

4) Tidak terdapat pengaruh tidak langsung antara kecemasan $\left(X_{1}\right)$ terhadap kemampuan komunikasi matematika siswa $(\mathrm{Y})$ melalui kemandirian belajar siswa $\left(\mathrm{X}_{1}\right)$ dengan berdasarkan nilai $\mathrm{t}_{\text {hitung }}<\mathrm{t}_{\text {tabel }}$ yaitu $0,131<1,665$ maka $\mathrm{H}_{0}$ diterima yang berarti bahwa tidak terdapat pengaruh tidak langsung antara kecemasan $\left(\mathrm{X}_{1}\right)$ terhadap kemampuan komunikasi matematika siswa (Y) melalui kemandirian belajar siswa $\left(\mathrm{X}_{1}\right)$.

\section{SARAN}

Berdasarkan kesimpulan dan implikasi penelitian dikemukakan beberapa saran sebagai berikut :

a. Banyak hal yang dapat meningkatkan kemampuan komunikasi matematika siswa di sekolah, diantaranya dengan meningkatkan kemandirian dan memperkecil kecemasan siswa dalam belajar. Peningkatan kemandirian siswa dapat membantu siswa dalam meningkatkan kemampuan komunikasi matematikanya dalam belajar.

b. Faktor lainnya yang dapat meningkatkan kemampuan komunikasi matematika siswa adalah dengan memberikan dorongan agar kemandirian belajar siswa lebih meningkat sehingga dapat meningkatkan prestasi belajarnya di sekolah. dorongan tersebut dapat bersifat internal maupun eksternal. Dorongan internal yang dimaksud adalah dengan meningkatkan kemandirian belajar siswa dalam menghadapi persoalan yang dihadapinya, sementar itu dorongan eksternal adalah dengan memberikan penghargaan bagi yang berprestasi dalam belajarnya di kelas. Kemandirian belajar sangat diperlukan untuk memberikan spirit bagi seseorang untuk melakukan aktifitas atau pekerjaannya. Untuk meningkatkan kemandirian tersebut, banyak hal yang dapat dikerjakan, diantaranya dengan memberikan penghargaan bagi siswa yang berprestasi dan sanksi bagi siswa yang selalu melanggar peraturan atau tata tertib.Oleh karena itu sebagai pendidik, guru harus rajin memberikan dorongan dan memberikan soal-soal latihan yang berkaitan dengan kemampuan komunikasi matematika bagi para siswanya agar dapat lebih meningkatkan prestasi dalam belajarnya. Untuk meningkatkan prestasi siswa diperlukan pendidik yang berkompeten, sistem pengajaran yang sesuai sehingga dapat melahirkan generasi muda yang dapat berguna untuk bangsa dan Negara. 
c. Mengingat keterbatasan peneliti, penelitian ini hanya dilakukan pada siswa SMA Negeri se Kecamatan Pasar Rebo, yaitu SMAN 104 dan SMAN 98 Jakarta kelas XI IPA, sehingga generalisasinya hanya berlaku bagi subjek yang memiliki karakteristik yang sama dengan subjek pada penelitian ini.oleh karena itu perlu dilakukan pengkajian penelitian lanjutan untuk mengungkap hal-hal lain yang mungkin dapat ditemukan dan dikembangkan dengan metode lain dan analisis yang beragam.

\section{DAFTAR PUSTAKA}

Ali, Muhammad. 2011. Psikologi Remaja: Perkembangan Peserta Didik. Bumi Aksara. Jakarta.

Basri, H. 2005. Pengantar Bisnis. BPFE. Yogyakarta.

Cangara, hafied H. 2006. Pengantar Ilmu Komunikasi. PT Raja Grafindo Persada. Jakarta.

Chabib, Toha. 2004. Teknik Evaluasi Pendidikan. PT Raja Grafindo Persada. Jakarta.

Depdikbud. 1989. Kamus Besar Bahasa Indonesia. Balai Pustaka. Jakarta.

Effendy, Onong Uchjana. 2007. Ilmu Komunikasi (Teori dan Praktek). Remaja Rosdakarya. Bandung.

Gunarsa, Singgih D. 2008. Psikologi Keperawatan. Gunung Mulia. Jakarta.

Iskandar. 2009. Psikologi Pendidikan: Sebuah Orientasi Baru. Gaung Persada Press. Jakarta.

Kridalaksana, Harimurti. 2008. Kamus Linguistik Edisi Keempat. Gramedia. Jakarta.

Maesarah, Sitti. 2010. Sikap siswa terhadap Ujian Nasional tahun ajaran 2007/008 dan tahun 2009/2010 bidang studi matematika di Kabupaten Belitung. Jurnal Penelitian dan Evaluasi Pendidikan. 1 (1), 92.

Maulidiyah. 2005. Pengaruh Peer Grup Terhadap Kemandirian Siswa Dasar Kelas IV Di MIN 2 Malang. Jurnal Penelitian dan Evaluasi Pendidikan. 1 (1), 92.

Mujiaman, Haris. 2007. Manajemen Pelatihan Berbasis Belajar Mandiri. Pustaka Belajar. Yogyakarta.

Mulyana, Deddy. 2008. Ilmu Komunikasi: Suatu Pengantar. Remaja Rosdakarya. Jakarta.

Parker, Deboar. K. 2006. Menumbuhkan Kemandirian dan Harga Diri Anak. Prestasi Pustakaraya. Jakarta. 
Research and Development Journal of Education

Poerwadarminta, W. J. S. 2007. Kamus Umum Bahasa Indonesia Edisi 3. Balai Pustaka. Jakarta.

Sappaile, Baso Intang. 2007. Hubungan kemampuan penalaran dalam matematika. Jurnal Pendidikan dan Kebudayaan. 069 (13), 989-990.

Sardiman. 2010. Pengajaran Terhadap Siswa. Remaja Rosdakarya. Bandung.

Slameto. 2010. Belajar dan Faktor-faktor yang Mempengaruhinya. Rineka Cipta. Jakarta.

Sudiarta, I Gusti Putu. 2007. Pengembangan pembelajaran berpendekatan tematik. Jurnal Pendidikan dan Kebudayaan. 069 (13), 1008.

Sudrajat, Akhmad. 2008. Pengertian Pendekatan, Strategi, Metode, Teknik dan Model Pembelajaran. Sinar Baru Algensindo. Bandung.

Sugihartono. 2007. Psikologi Pendidikan. UNY Press. Yogyakarta.

Sugiyono. 2010. Metode Penelitian Pendidikan, Pendekatan Kuntitatif, Kualitatif, dan $R \& D$. Alfabeta. Bandung.

Suhartono, Suparlan. 2008. Wawasan Pendidikan: Sebuah Pengantar Pendidikan. ArRuzz Media. Yogyakarta.

Sukmadinata, Nana Syaodih. 2011. Metode Penelitian Pendidikan. Remaja Rosdakarya Offset. Bandung.

Syarifudin, Huda. 2007. Hubungan Konsep Diri dengan Kemadirian Belajar Siswa Kelas VIII SMP N 3 Waru, Fakultas Ilmu Pendidikan Program Studi Bimbingan dan Konseling. Semarang : IKIP PGRI. 03111145 (15)

Trianto. 2010. Mengembangkan Model Pembelajaran Tematik. Prestasi Pustakaraya. Jakarta.

Turmudi. 2008. Landasan Filsafat dan Teori Pembelajaran Matematika (Berparadigma Eksploratif dan Investigatif). Leuser Cipta Pustaka. Jakarta.

Wahyudin. 2008. Pembelajaran dan Model-model Pembelajaran. Ipa Abong. Jakarta.

Yusdi, Milman. 2010. Kamus Umum Bahasa Indonesia. Pustaka Sinar Harapan. Jakarta. 